\title{
Leukokinetic Studies. X. Blood Granulocyte Kinetics in Chronic Myelocytic Leukemia*
}

\author{
J. W. Athens, $\dagger$ S. O. RaAb, O. P. HaAb, D. R. Boggs, $\$$ H. Ashenbrucker, \\ G. E. Cartwright, and M. M. Wintrobe \\ (From the Department of Medicine, University of Utah School of Medicine, \\ Salt Lake City, Utah)
}

By the transfusion of granulocytes labeled in vitro with diisopropyl fluorophosphate (DFP ${ }^{32}$ ), it is possible to measure the size of the total blood granulocyte pool (TBGP), the distribution of granulocytes in the two subcompartments thereof, the blood granulocyte half disappearance time $\left(t_{1}\right)$, and the blood granulocyte turnover rate (GTR) (1-3). In preliminary reports from this laboratory (4-6) and in reports from other laboratories $(7,8)$ an increase in TBGP size, prolongation of blood granulocyte $t_{\frac{1}{2}}$, and an increase in GTR have been described in a few patients with chronic myelocytic leukemia. In the present report 43 studies carried out on 29 patients with chronic myelocytic leukemia (CML) in various stages of their disease have been analyzed in an attempt to gain an understanding of these deviations from normal granulocyte kinetics. In addition, several studies designed to evaluate the cause of the long $t_{\frac{1}{2}}$ values in patients with CML are presented. Similar studies of granulocyte kinetics in patients with polycythemia vera, subacute or chronic infections, myelofibrosis, or diseases of other kinds are presented in a companion paper.

\section{Methods}

In vitro labeled (1), autologous granulocytes were infused in 43 studies on patients with CML. Of these, 23 studies were performed on patients with a blood granulocyte concentration greater than 30,000 per $\mathrm{mm}^{3}$

* Submitted for publication November 9, 1964; accepted January 14, 1965.

This investigation was supported by a research grant (AM-04489) and 2 graduate training grant (2A-5098) from the National Institute of Arthritis and Metabolic Diseases, Bethesda, Md.

$\dagger$ Address requests for reprints to Dr. J. W. Athens, Department of Internal Medicine, Salt Lake County General Hospital, 175 East 21st South St., Salt Lake City, Utah 84115.

†Leukemia Society Scholar.
(Table I), 8 studies were carried out on patients with granulocyte concentrations between 10,000 and 30,000 per $\mathrm{mm}^{\mathrm{s}}$ (Table II), and 12 were made on patients with granulocyte concentrations less than 10,000 per $\mathrm{mm}^{3}$ ( Table III). These groups roughly correspond to patients with CML in relapse, partial relapse (or remission), and remission, respectively, though the classification is obviously an arbitrary one. Immature granulocytes (myeloblasts, promyelocytes, myelocytes, and metamyelocytes) were present in the blood of most of the patients ( $\mathrm{Ta}$ bles I, II, and III), but were generally present in lower numbers in patients in remission.

Repeated leukocyte and 200 cell differential counts were done on each patient while under study. Throughout the course of each study the granulocyte count remained stable. Fourteen studies were carried out while patients were receiving therapy with busulfan or colcemide, and these are indicated in the tables.

TBGP size was measured by means of the isotope dilution principle and calculated in two ways. The "determined" TBGP was calculated from the mean of triplicate blood granulocyte radioactivity values obtained 5 minutes after completion of the infusion $\left(t_{0}\right)$. The "extrapolated" TBGP was calculated from the blood granulocyte radioactivity value obtained by extrapolating the blood granulocyte radioactivity curve back to the ordinate. For reasons that will be discussed below, the determined TBGP is believed to be the more accurate value, and therefore only determined TBGP values are given in the tables. In autologous studies the patient received his own labeled blood, whereas in the isologous transfusions labeled blood from a compatible donor was infused.

In the labeled bone marrow infusion studies marrow was aspirated from the iliac crest and suspended by agitation in $10 \mathrm{ml}$ of acid-citrate-dextrose (ACD) solution, $\mathrm{DFP}^{32}$ was added to give a concentration of about $3 \mu \mathrm{g}$ per $\mathrm{ml}$, and the mixture was incubated for 1 hour at room temperature. The labeled marrow cells were then transfused intravenously from a standard recipient set (Fenwal HD-92D), the filter of which removed any large marrow particles.

\section{Results}

Blood granulocyte radioactivity disappearance curves. In 24 studies a single exponential blood 
TABLE I

Blood granulocyte kinetic values in patients with chronic myelocytic leukemia in relapse compared with those in normal subjects*

\begin{tabular}{|c|c|c|c|c|c|c|c|c|c|c|c|c|c|c|}
\hline & $\begin{array}{c}\text { Study } \\
\text { no. }\end{array}$ & G & Blasts & Pro & Myelo & Meta & Band & Seg & TBGP & CGP & $t_{t}$ & GTR & $\begin{array}{l}\text { Type } \\
\text { of } \\
\text { curve }\end{array}$ & $\begin{array}{l}\text { Treat- } \\
\text { ment }\end{array}$ \\
\hline \multirow{25}{*}{$\begin{array}{c}\text { Mean } 56 \\
\text { normals } \\
95 \% \text { limits }\end{array}$} & & per $m m^{3}$ & $\%$ & $\%$ & $\%$ & $\%$ & $\%$ & $\%$ & \multicolumn{2}{|c|}{$\times 10^{7} \mathrm{G} / \mathrm{kg}$} & \multicolumn{3}{|c|}{$\begin{array}{c}G / \mathrm{kg} / \mathrm{day} \\
\times 10^{7}\end{array}$} & \\
\hline & & $\begin{array}{c}4,650 \\
2,250-6,600\end{array}$ & & & & & & & $\begin{array}{c}62.5 \\
(14-108)\end{array}$ & $\begin{array}{c}31.4 \\
(19-44)\end{array}$ & $\begin{array}{c}6.7 \\
(4-10)\end{array}$ & $\begin{array}{c}163 \\
(50-340)\end{array}$ & & \\
\hline & V-136 & 486,550 & 0.5 & 5.5 & 12.5 & 10.0 & 40.5 & 28.0 & 9,514 & 3,694 & 78 & 2,029 & A & $4 \mathrm{mg} \mathrm{Bu}$ \\
\hline & II-26 & 298,680 & 7.5 & 6.0 & 13.0 & 13.5 & 28.0 & 22.5 & 5,453 & 2,114 & 89 & 1,019 & B & o \\
\hline & V-48 & 249,240 & 2.0 & 3.5 & 7.5 & 8.0 & 38.5 & 33.5 & 4,592 & 1,816 & 76 & 1,004 & $\mathbf{A}$ & $\mathbf{0}$ \\
\hline & VI-12 & 494,680 & 4.5 & 10.5 & 26.0 & 12.5 & 30.5 & 7.5 & 4,124 & 3,724 & $\dagger$ & & $\mathrm{C}$ & 0 \\
\hline & V-106 & 222,700 & 2.5 & 6.0 & 10.0 & 7.5 & 36.5 & 31.5 & 2,589 & 1,463 & 57 & 755 & A & 0 \\
\hline & II-84 & 197,350 & Blood & smear & not availa & ble & & & 2,430 & 1,285 & 72 & 561 & B & o \\
\hline & V-66 & 150,075 & 0.5 & 3.0 & 7.0 & 12.0 & 36.5 & 35.5 & 2,247 & 1,074 & 60 & 623 & A & $2 \mathrm{mg} \mathrm{Bu}$ \\
\hline & III-126 & 88,970 & 6.0 & 3.5 & 4.5 & 8.0 & 41.5 & 26.5 & 2,009 & 657 & 34 & 983 & A & 0 \\
\hline & III-102 & 81,288 & 1.5 & 3.0 & 10.0 & 11.0 & 42.0 & 19.0 & 1,853 & 587 & 46 & 670 & B & 0 \\
\hline & III-106 & 108,113 & 1.0 & 2.5 & 4.5 & 5.5 & 39.5 & 31.0 & 1,733 & 809 & 76 & 379 & A & 0 \\
\hline & V-10 & 59,508 & 2.5 & 2.5 & 11.0 & 9.0 & 28.0 & 38.0 & 1,513 & 388 & 78 & 559 & $\mathbf{A}$ & 0 \\
\hline & I-159 & 54,735 & 1.0 & 1.5 & 11.5 & 11.0 & 29.0 & 36.0 & 1,435 & 376 & 26 & 918 & $\mathbf{A}$ & 0 \\
\hline & VI-42 & 70,110 & 1.0 & 1.0 & 12.5 & 7.5 & 46.0 & 20.5 & 1,181 & 524 & $\dagger$ & & C & $4 \mathrm{mg} \mathrm{Bu}$ \\
\hline & II-82 & 89,775 & 1.5 & 1.5 & 7.5 & 10.5 & 37.0 & 35.5 & 1,045 & 561 & 32 & 543 & $\mathbf{A}$ & 0 \\
\hline & VII-88 & 84,430 & & & 14.5 & 15.0 & 27.5 & 35.5 & 1,012 & 591 & 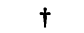 & & C & 0 \\
\hline & IV-96 & 56,088 & 2.5 & 4.0 & 9.5 & 16.5 & 38.5 & 24.0 & 909 & 399 & 67 & 226 & B & $\mathbf{0}$ \\
\hline & VII-48 & 69,501 & 2.5 & 1.5 & 15.0 & 12.0 & 38.0 & 13.0 & 890 & 547 & 55 & 269 & A & 0 \\
\hline & V-124 & 44,550 & 1.5 & 0.5 & 3.0 & 5.0 & 39.0 & 39.0 & 849 & 322 & 25 & 565 & A & $4 \mathrm{mg} \mathrm{Bu}$ \\
\hline & $\mathrm{I}-200$ & 59,833 & & 0.5 & 11.0 & 11.0 & 30.5 & 36.5 & 762 & 376 & 40 & 317 & B & 0 \\
\hline & III-172 & 47,499 & & & 8.0 & 13.0 & 41.0 & 26.0 & 695 & 333 & $\dagger$ & & C & 0 \\
\hline & VII-74 & 35,363 & 1.0 & 3.5 & 4.5 & 10.0 & 25.5 & 35.0 & 689 & 279 & $\dagger$ & & C & 0 \\
\hline & IV-92 & 73,515 & 1.0 & 2.0 & 12.5 & 10.0 & 33.5 & 32.0 & 681 & 520 & $\dagger$ & & C & $6 \mathrm{mg} \mathrm{Bu}$ \\
\hline & III-128 & 49,855 & 2.5 & 2.5 & 4.5 & 2.0 & 28.0 & 36.0 & 680 & 377 & 78 & 145 & $\mathbf{A}$ & 0 \\
\hline
\end{tabular}

* $\mathrm{G}=$ granulocytes; Blasts = myeloblasts $;$ Pro = promyelocytes; Myelo = myelocytes; Meta = metamyelocytes; Seg = segmented neu trophils; TBGP = total blood granulocyte pool; CGP = circulating granulocyte pool; GTR $=$ granulocyte turnover rate; Bu = busulfan.

$\dagger$ No single t value measurable but blood granulocyte radioactivity remained elevated for considerably longer than in normal subjects (see Figure 1).

granulocyte specific activity (BGSA) ${ }^{1}$ curve was obtained. These curves are designated type "A" (Figure 1). In five of the studies on patients in relapse and in two patients in remission a rapid fall in blood granulocyte radioactivity took place during the first 3 hours after infusion of the labeled blood. Thereafter a single exponential disappearance curve was found. Such curves are designated type " $B$ " in Figure 1 and Tables I and III. In twelve studies a changing granulocyte disappearance rate was observed, and a single value for $t_{\frac{1}{3}}$ could not be obtained. These curves are referred to as type "C" in Figure 1 and Tables I, II, and III.

In type A curves the determined and extrapolated TBGP values were the same. In type B curves the values obtained by extrapolating the second phase of the curve to the ordinate, the extrapolated TBGP, resulted in a TBGP value

1 Expressed as counts per minute per milligram granulocyte nitrogen. considerably larger than the determined values. In type $C$ curves no extrapolated TBGP could be calculated.

Effect of cell damage on BGSA curve. To evaluate cell damage as a possible explanation for the type B and C BGSA curves just described, blood was withdrawn from normal subjects, incubated for time periods of from 2 to 24 hours, labeled with $\mathrm{DFP}^{32}$, and then returned to the circulation of the donor. The configuration of the BGSA curve and the size of the determined and extrapolated TBGP in these subjects are summarized in Table IV.

When blood was incubated for 2 hours, labeled with $\mathrm{DFP}^{32}$, and infused, type A curves were obtained. When blood was incubated for 8 or 16 hours predominantly type B curves resulted, and when blood was incubated for 24 hours the BGSA was so low several hours after completion of the infusion that often no BGSA curve could be obtained. No type $\mathrm{C}$ curves were encountered in 
TABLE II

Chronic myelocytic leukemia in partial relapse or remission*

\begin{tabular}{|c|c|c|c|c|c|c|c|c|c|c|c|c|c|}
\hline $\begin{array}{c}\text { Study } \\
\text { no. }\end{array}$ & G & Blasts & Pro & Myelo & Meta & Band & Seg & TBGP & CGP & $t_{1}$ & GTR & $\begin{array}{c}\text { Type } \\
\text { of } \\
\text { curve }\end{array}$ & $\begin{array}{l}\text { Treat- } \\
\text { ment }\end{array}$ \\
\hline & per $m m^{2}$ & $\%$ & $\%$ & $\%$ & $\%$ & $\%$ & $\%$ & \multicolumn{2}{|c|}{$\times 10^{7} \mathrm{G} / \mathrm{kg}$} & hrs & $\begin{array}{c}G / \mathrm{kg} / d a y \\
\times 10^{7}\end{array}$ & & \\
\hline III-32 & 20,792 & 1.0 & 2.0 & 7.5 & 4.5 & 30.0 & 37.5 & 644 & 135 & 30.0 & 357 & $\mathbf{A}$ & $8 \mathrm{mg} \mathrm{Bu}$ \\
\hline I-163 & 26,522 & 5.0 & 2.5 & 5.0 & 4.5 & 25.5 & 44.0 & 620 & 182 & 36.0 & 286 & A & 0 \\
\hline VII-66 & 15,770 & 0.5 & 0.5 & 5.0 & 11.0 & 30.5 & 36.5 & 413 & 130 & & & C & o \\
\hline V-180 & 18,426 & 0.5 & 1.0 & 10.0 & 11.5 & 24.5 & 35.5 & 304 & 114 & & & C & $4 \mathrm{mg} \mathrm{Bu}$ \\
\hline III-104 & 16,632 & & 4.0 & 5.5 & 7.5 & 7.5 & 56.5 & 272 & 117 & 10.6 & 325 & A & 0 \\
\hline V-186 & 22,605 & 1.5 & 3.0 & 5.0 & 5.5 & 20.0 & 54.0 & 263 & 165 & & & C & 0 \\
\hline$V-130$ & 12,549 & & 1.0 & 6.0 & 4.5 & 17.0 & 47.0 & 187 & 86 & & & C & 0 \\
\hline V-148 & 11,106 & & 1.5 & 9.5 & 7.5 & 10.0 & 56.5 & 128 & 81 & 7.1 & 92 & $\mathbf{A}$ & $4 \mathrm{mg} \mathrm{Bu}$ \\
\hline
\end{tabular}

* See Table I for ionsabbreviat and footnotes.

any of these studies. In addition, when blood was incubated for 8,16 , or 24 hours, labeled, and infused, a significant portion of the labeled cells was apparently removed from circulation during the infusion since the determined TBGP values were unusually large for normal subjects with normal granulocyte counts. The removal of damaged cells from the circulation apparently continued for several hours as indicated by the initial rapid fall in type B curves and the extremely large extrapolated TBGP values in such studies. There was no cell clumping or other obvious reason for the rapid removal of these cells from the circulation.

Relationship between granulocyte count and $T B G P$ size. There was good correlation between granulocyte concentration and determined TBGP size in the 43 studies on patients with CML $(\mathrm{r}=+0.76, \mathrm{p}=<0.001)$. This relationship for the 31 studies on patients in relapse and in partial relapse is shown in Figure 2.

In all patients with granulocyte counts greater than 10,000 per $\mathrm{mm}^{3}$ the TBGP was increased in size, and in four of the eight patients with granulocyte counts in the normal range [less than 7,500 per $\mathrm{mm}^{3}(9)$ ] the TBGP was greater than the upper limit of normal.

In the seven studies in which type $B$ curves were obtained the TBGP calculated from the determined $t_{0}$ values was in good agreement with that expected from the granulocyte count (Figure 2), whereas the TBGP size calculated from the extrapolated $t_{0}$ value was unusually large.

Distribution of granulocytes in the TBGP. The distribution of cells in the TBGP of patients with chronic myelocytic leukemia (CGP/TBGP, circulating: total blood granulocyte pool ratio) was

TABLE III

Chronic myelocytic leukemia in remission*

\begin{tabular}{|c|c|c|c|c|c|c|c|c|c|c|c|c|c|}
\hline $\begin{array}{c}\text { Study } \\
\text { no. }\end{array}$ & G & Blasts & Pro & Myelo & Meta & Band & Seg & TBGP & CGP & t t & GTR & $\begin{array}{l}\text { Type } \\
\text { of } \\
\text { cruve }\end{array}$ & Treatment \\
\hline & per $m m^{3}$ & $\%$ & $\%$ & $\%$ & $\%$ & $\%$ & $\%$ & \multicolumn{2}{|c|}{$\times 10^{7} \mathrm{G} / \mathrm{kg}$} & hrs & $\begin{array}{c}\mathrm{G} / \mathrm{kg} / \mathrm{da} \\
\times 10^{7}\end{array}$ & & \\
\hline II-190 & 9,116 & & 1.5 & 2.0 & 1.0 & 15.0 & 59.0 & 252 & 65 & 7.8 & 537 & $\mathbf{A}$ & 0 \\
\hline V-8 & 6,799 & & & 5.5 & 1.5 & 4.0 & 73.0 & 136 & 49 & 5.4 & 419 & $\mathbf{A}$ & 0 \\
\hline II-172 & 6,391 & 1.0 & & & & 5.5 & 74.0 & 128 & 39 & 6.1 & 349 & $\mathbf{A}$ & Colcemide \\
\hline III-140 & 5,472 & & & 5.5 & 5.0 & 10.5 & 60.5 & 118 & 35 & 10.3 & 191 & $\mathbf{A}$ & 0 \\
\hline V-164 & 9,173 & & 1.0 & 4.0 & 10.0 & 25.0 & 32.5 & 106 & 67 & $t$ & & C & 0 \\
\hline II-188 & 5,720 & 0.5 & 1.5 & 2.0 & 1.0 & 5.5 & 60.5 & 101 & 45 & 8.6 & 195 & $\mathbf{A}$ & 0 \\
\hline III-174 & 7,703 & 1.5 & 1.0 & 3.5 & 7.5 & 20.0 & 44.5 & 85 & 57 & 9.6 & 147 & $\mathbf{A}$ & $4 \mathrm{mg} \mathrm{Bu}$ \\
\hline III-114 & 6,645 & & & 4.5 & 1.5 & 18.0 & 56.5 & 82 & 64 & 7.5 & 182 & $\mathbf{A}$ & Colcemide \\
\hline II-186 & 4,635 & 1.0 & & 2.0 & 3.0 & 17.5 & 41.5 & 71 & 31 & 7.0 & 169 & $\mathbf{A}$ & o \\
\hline VII-82 & 1,943 & & & & 4.0 & 13.0 & 41.5 & 42 & 13 & $t$ & & C & 0 \\
\hline IV-76 & 7,052 & 2.0 & 1.5 & 6.0 & 11.0 & 27.0 & 29.5 & 242 & 52 & 40.5 & 99 & B & $\ddagger$ \\
\hline III-38 & 7,224 & 2.5 & & 3.0 & 9.0 & 57.5 & 18.5 & 88 & 51 & 45.0 & 33 & B & $\ddagger$ \\
\hline
\end{tabular}

* See Table I for abbreviations.

+ No single ti value measurable.

$\ddagger$ Off therapy 3 days. 


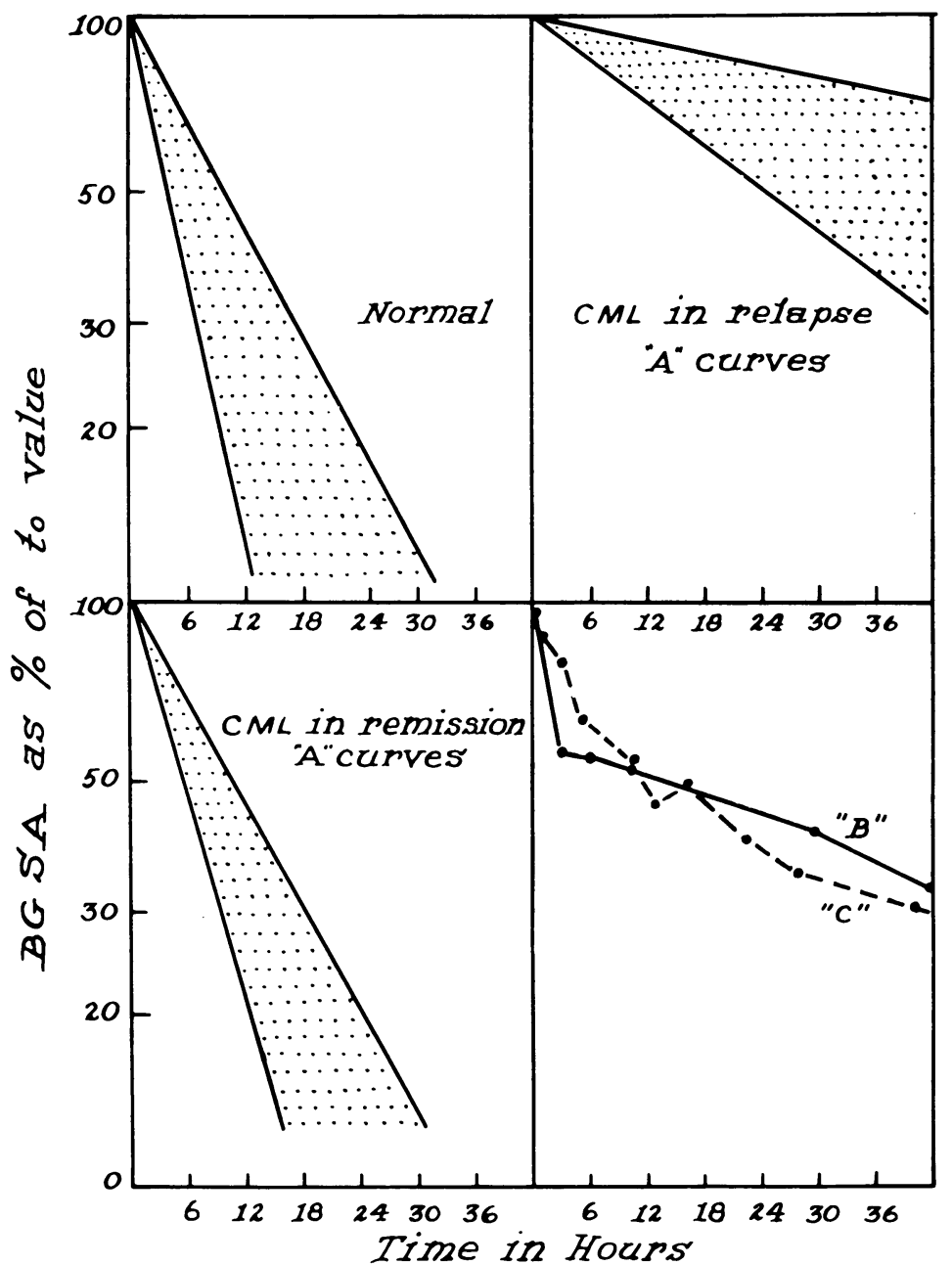

Fig. 1. Blood granulocyte specific activity (BGSA) curves obtained in PATIENTS WITH CHRONiC MYELOCYTIC LEUKEMia (CML) IN RELAPSE AND REMISSION COMPARED WITH THOSE IN NORMAL SUBJECTS (FIRST THREE PANELS). Examples of type " $\mathrm{B}$ " and "C" curves are shown in the last panel.

TABLE IV

Effect of time of incubation of blood on the configuration of the blood granulocyte radioactivity curve and on TBGP size in normal subjects*

\begin{tabular}{cclcc}
\hline \hline $\begin{array}{c}\text { Incubation } \\
\text { time }\end{array}$ & $\begin{array}{c}\text { No. of } \\
\text { studies }\end{array}$ & \multicolumn{1}{c}{ Curve type } & $\begin{array}{c}\text { Determined } \\
\text { TBGP }\end{array}$ & $\begin{array}{c}\text { Extrapolated } \\
\text { TBGP }\end{array}$ \\
\hline $\begin{array}{c}h r s \\
2\end{array}$ & 4 & 4 Type A & 113 & $\times 10^{7} G / k g$ \\
113 \\
\end{tabular}

* See Table I for abbreviations. 
compared with the distribution found in normal subjects (Figure 3 ). There was no difference between these groups. This is in contrast to the finding in myelofibrosis and in some cases of polycythemia vera where a shift of cells into marginal sites (MGP) was noted whenever the TBGP was found to be increased in size (10).

Four patients were given epinephrine infusions $(0.5 \mathrm{mg}$ diluted in $50 \mathrm{ml}$ of isotonic saline injected over 5 to 7 minutes) to determine whether granulocytes in the MGP could be mobilized as readily in patients with chronic myelocytic leukemia as in normal subjects (2). An increase in granulocyte count resulted from the infusion of epinephrine (Table V). No alteration in differential count or blood granulocyte radioactivity accompanied the mobilization of 45 to $71 \%$ of the cells in the MGP of these patients.

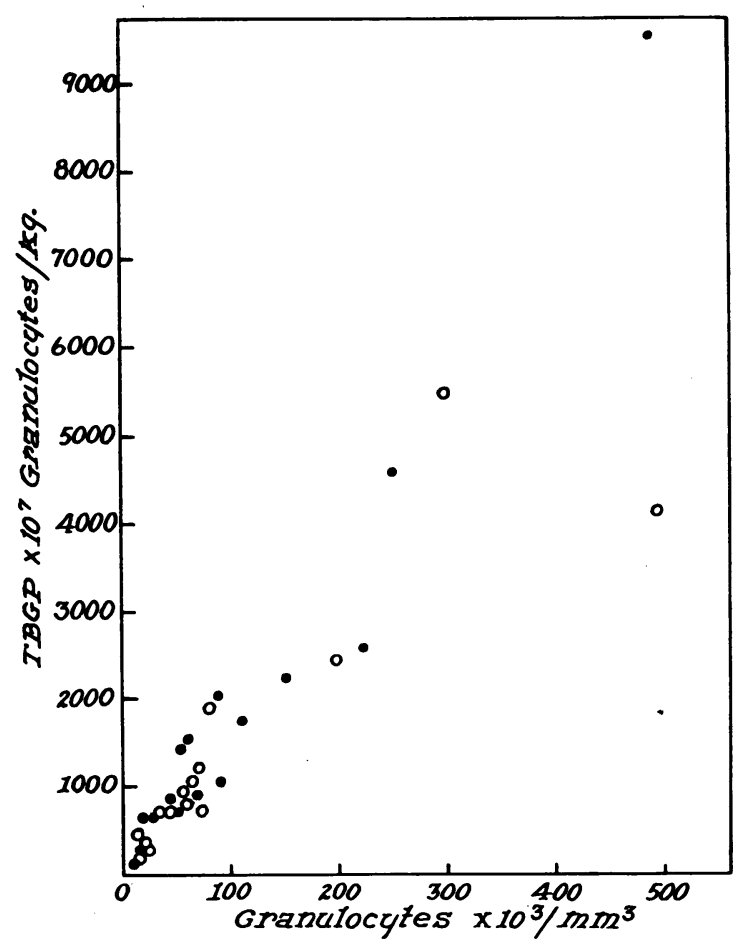

Fig. 2. RELATIONSHIP BETWEen BLOOD GRANULOCYTE COUNT AND TOTAL BLOOD GRANULOCYTE POOL (TBGP) SIZE IN PATIENTS WITH CHRONIC MYELOCYTIC LEUKEMIA. The values on patients in remission are not plotted because of the congestion that would result in the lower left corner of the graph. The solid circles (O) represent the values obtained in patients with type " $A$ " curves. The hollow circles $(O)$ are the TBGP values (calculated from "determined" rather than "extrapolated" $t_{0}$ radioactivity) obtained in patients with type " $B$ " and "C" curves.

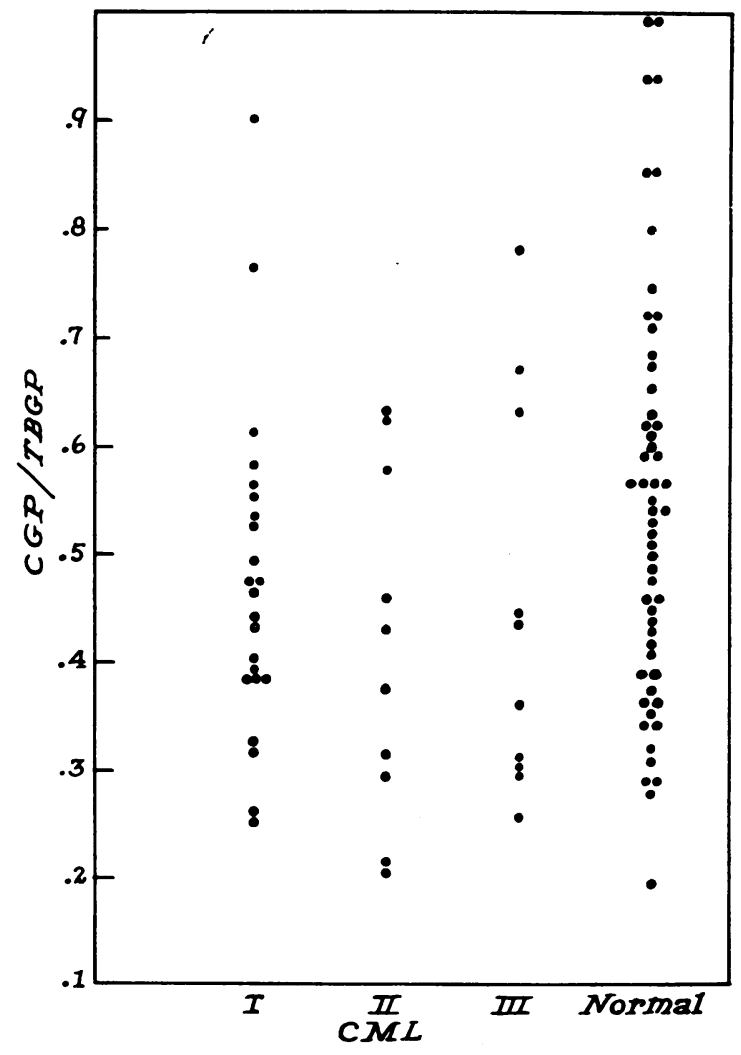

Fig. 3. Distribution OF GRANUlocytes as REPRESENTED BY THE RATIO, CIRCULATING GRANULOCYTE POOL TO TOTAL BLOOD GRANULOCYTE POOL (CGP/TBGP), IN THE TBGP OF PATIENTS WITH CHRONIC MYELOCYTIC LEUKEMIA (CML) IN RELAPSE (I), PARTIAL RELAPSE OR REMISSION (II), AND IN REMISSION (III), AS COMPARED TO NORMAL SUBJECTS.

Granulocyte disappearance curve. The curves of BGSA encountered in these studies are illustrated in Figure 1. Regardless of curve shape the BGSA remained elevated for a prolonged period in all patients with chronic myelocytic leukemia in relapse (Table I and Figure 1). Among patients with granulocyte counts less than 10,000 per $\mathrm{mm}^{3}, 8$ of the $10 \mathrm{t}_{3}$ values were normal in spite of the persistence of a few immature granulocytes in the blood (Table III and Figure 1). The two striking exceptions to this were patients IV-76 and III-38, both of whom had just completed their fourth and fifth courses of therapy, respectively, and soon thereafter entered the terminal phase of their disease. In the patients in partial relapse (or remission) $t_{i}$ values intermediate between those encountered in the two groups just mentioned were observed (Table II). 
TABLE $\mathrm{V}$

Influence of epinephrine infusion on blood granulocyte count and granulocyte radioactivity in patients with chronic myelocytic leukemia*

\begin{tabular}{|c|c|c|c|c|c|c|}
\hline \multirow{2}{*}{$\begin{array}{c}\text { Study } \\
\text { no. }\end{array}$} & \multirow{2}{*}{$\begin{array}{c}\text { Time of } \\
\text { epinephrine } \\
\text { infusion } \dagger\end{array}$} & \multicolumn{2}{|c|}{$\mathrm{G}$ per $\mathrm{mm}^{3}$} & \multirow{2}{*}{$\begin{array}{l}\% \text { of MGP } \\
\text { mobilized }\end{array}$} & \multicolumn{2}{|c|}{ G Radioactivity } \\
\hline & & Before & After & & Before & After \\
\hline $\begin{array}{l}\text { III-32 } \\
\text { III-172 } \\
\text { IV-76 } \\
\text { V-130 }\end{array}$ & $\begin{array}{l}t_{0} \\
t_{52} \\
t_{29} \\
t_{47}\end{array}$ & $\begin{array}{r}20,790 \\
56,980 \\
8,672 \\
11,914\end{array}$ & $\begin{array}{r}70,600 \\
101,130 \\
22,869 \\
20,604\end{array}$ & $\begin{array}{l}64 \\
71 \\
45 \\
62\end{array}$ & $\begin{array}{r}76 \\
250 \\
159\end{array}$ & $\begin{array}{r}81 \\
242 \\
169\end{array}$ \\
\hline
\end{tabular}

* See Table I for abbreviations. MGP = marginal granulocyte pool.

$\dagger$ The values $t_{0}, t_{52}$, etc., refer to the time after completion of the infusion of autologous, DFP ${ }^{32}$-labeled blood that the epinephrine infusions were given.

Since the $t_{\frac{1}{2}}$ was markedly prolonged in CML patients with high granulocyte concentrations and large TBGP, the relationship between the $t_{1}$ and TBGP was examined. We have previously reported poor correlation between the $t_{1}$ and TBGP size, as calculated from extrapolated $t_{0}$ values $(6)$. In contrast, the correlation between the $t_{\frac{1}{2}}$ and

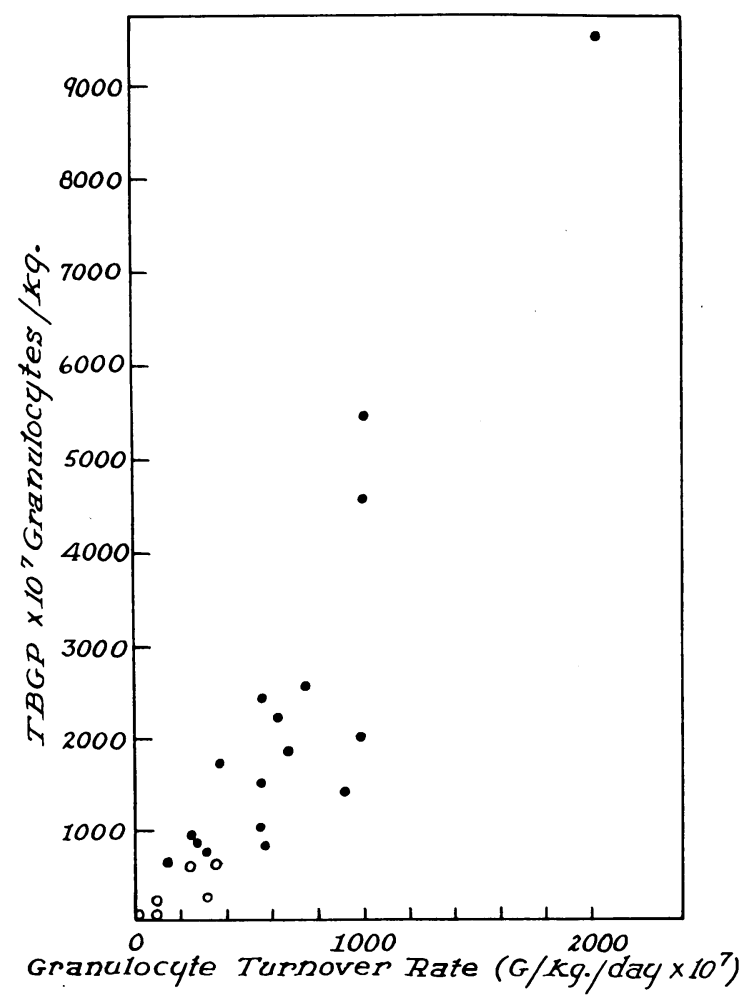

Fig. 4. Relationship Between the GRANUlocyte TURNOVER RATE (GTR) AND THE TOTAL BLOOD GRANULOCYTE POOL (TBGP) IN PATIENTS WITH CHRONIC MYELOCYTIC LEUKEMIA IN RELAPSE AND PARTIAL RELAPSE. The solid circles (O) represent patients in relapse. The hollow circles (O) refer to patients in partial relapse. the TBGP calculated from determined $t_{0}$ values was $+0.67(p=<0.001)$. Patients IV-76 and III-38 (Table III), mentioned above, were excluded from this calculation.

Because the $t_{1}$ values in patients with CML in relapse were unusually long as compared to those in normal subjects and in patients with other types of neutrophilia without increased numbers of immature granulocytes in the blood (10), the relationship between the $t_{\frac{1}{2}}$ and the proportion of immature granulocytes in the blood was examined. In the 28 patients with $t_{\frac{1}{2}}$ values and differential counts (Tables I, II, and III) the correlations between $t_{1}$ values and the proportion of different types of neutrophilic granulocytes were calculated (Patients IV-76, III-38, and II-84 were excluded). The correlation between the $t_{\frac{1}{2}}$ and the proportion of myelocytes was $r=+0.58, p=<$ 0.005 , and between the $t_{\frac{1}{2}}$ and the sum of myelocyte and metamyelocyte percentages it was $r=+0.61$, $\mathrm{p}=<0.001$. Since promyelocytes and myeloblasts are not labeled with $\operatorname{DFP}^{32}$ (11), no attempt was made to correlate $t_{1}$ and the proportion of these cell forms present in the blood.

Relationship between the TBGP and GTR. In patients in relapse the GTR was usually moderately increased above normal (Table I and Figure 4). In patients in remission the GTR values were normal or nearly normal (Table III), whereas in patients in partial relapse the values overlapped the other two groups. The correlation between GTR and TBGP was +0.90 ( $\mathrm{p}=$ $<0.001$ ).

Isologous transfusions. In an attempt to discover the reason for the slow decrease in blood granulocyte radioactivity in patients with CML, normal blood was labeled with $\mathrm{DFP}^{32}$ and trans- 
TABLE VI

Isologous transfusion studies: normal blood to patients with chronic myelocytic leukemia*

\begin{tabular}{|c|c|c|c|c|c|}
\hline Study no. & Recipient & TBGP & CGP & $t_{\frac{1}{3}}$ & $\begin{array}{c}\text { Type of } \\
\text { curve }\end{array}$ \\
\hline & $G$ per $\mathrm{mm}^{3}$ & \multicolumn{2}{|c|}{$\times 10^{7} \mathrm{G} / \mathrm{kg}$} & hrs & \\
\hline $\begin{array}{l}\text { II-162 } \\
\text { III-8 } \\
\text { VI-52 } \\
\text { VI-72 }\end{array}$ & $\begin{array}{l}23,250 \\
24,840 \\
29,205 \\
49,940\end{array}$ & $\begin{array}{l}274 \\
623 \\
522 \\
724\end{array}$ & $\begin{array}{l}148 \\
178 \\
207 \\
363\end{array}$ & $\begin{array}{r}10.7 \\
8.0 \\
6.8 \\
7.7\end{array}$ & $\begin{array}{l}\text { A } \\
\text { A } \\
\text { A } \\
\text { A }\end{array}$ \\
\hline
\end{tabular}

* See Table I for abbreviations.

fused into compatible recipients with $\mathrm{CML}$ (in relapse and partial relapse), and blood from patients with CML in relapse was labeled with $\mathrm{DFP}^{32}$ and transfused into hematologically normal, compatible recipients with incurable carcinomas.

In four of five patients with CML given normal cells, the normal neutrophils left the blood in a random manner, $t_{1}$ values being normal (Table VI). The fifth study was technically unsatisfactory.

In three hematologically normal subjects given labeled blood from patients with CML (Table VII) the blood granulocyte radioactivity curves were complex (Figure 5, curves 1, 2, and 3). Nevertheless, the blood granulocyte radioactivity remained elevated for considerably longer periods than when normal blood was given to isologous recipients (1). This was observed in spite of the fact that in no instance was a recipient transfused with more than about half as many granulocytes as were calculated to be present in his TBGP.

Infusion of $D F P^{32}$-labeled autologous bone marrow. To further evaluate the role of immaturity of leukocytes as a possible reason for the slow decrease in BGSA in patients with CML, two subjects were given infusions of $\mathrm{DFP}^{32}$-la- beled, autologous bone marrow cell suspensions. One study was unsatisfactory because of low radioactivity values. In the second study the labeled cells left the blood in a complex manner (Figure 5, curve 4), but the granulocyte radioactivity was still elevated after 8 days. This subject received 700 million labeled granulocytes, a number equal to about $3 \%$ of his TBGP.

Patients in whom several studies were carriod out. In two patients three and four studies respectively were carried out at various stages of their disease. When the $t_{\frac{1}{2}}$ obtained in the several studies on each patient was compared with the TBGP size (Figure 6), it was evident that at low cell counts and thus smaller TBGP the $t_{i}$ was shorter than when the cell count was higher and the TBGP larger. The blood differential count changed very little during the course of therapy in Patient V-48, whereas in patient III= 102 the proportion of myelocytes plus metamyelocytes decreased from 21 to $3 \%$ and the juvenile plus polymorphonuclear percentage increased from 61 to 74 .

\section{Discussion}

A ten- to 150-fold increase in TBGP size has been demonstrated in patients with CML in re-

TABLE VII

Isologous transfusion studies: chronic myelocytic leukemia blood to normal subjects*

\begin{tabular}{|c|c|c|c|c|c|}
\hline \multirow[b]{2}{*}{ Study no. } & \multirow[b]{2}{*}{ Donor } & \multicolumn{4}{|c|}{ Recipient } \\
\hline & & TBGP & CGP & $\begin{array}{l}\text { G radioactivity } \\
\text { disappearance }\end{array}$ & $\begin{array}{l}\text { Type of } \\
\text { curve }\end{array}$ \\
\hline & $G$ per $m^{2} m^{3}$ & \multicolumn{2}{|c|}{$\times 10^{7} \mathrm{G} / \mathrm{kg}$} & & \\
\hline $\begin{array}{l}\text { II-234 } \\
\text { IV-4 } \\
\text { V-12 }\end{array}$ & $\begin{array}{l}57,024 \\
50,030 \\
51,238\end{array}$ & $\begin{array}{r}219 \\
75 \\
123\end{array}$ & $\begin{array}{l}35 \\
22 \\
28\end{array}$ & $\begin{array}{l}\text { Prolonged } \\
\text { Prolonged } \\
\text { Prolonged }\end{array}$ & $\begin{array}{l}\text { B } \\
\text { B } \\
\text { C }\end{array}$ \\
\hline
\end{tabular}

* See Table I for abbreviations. 


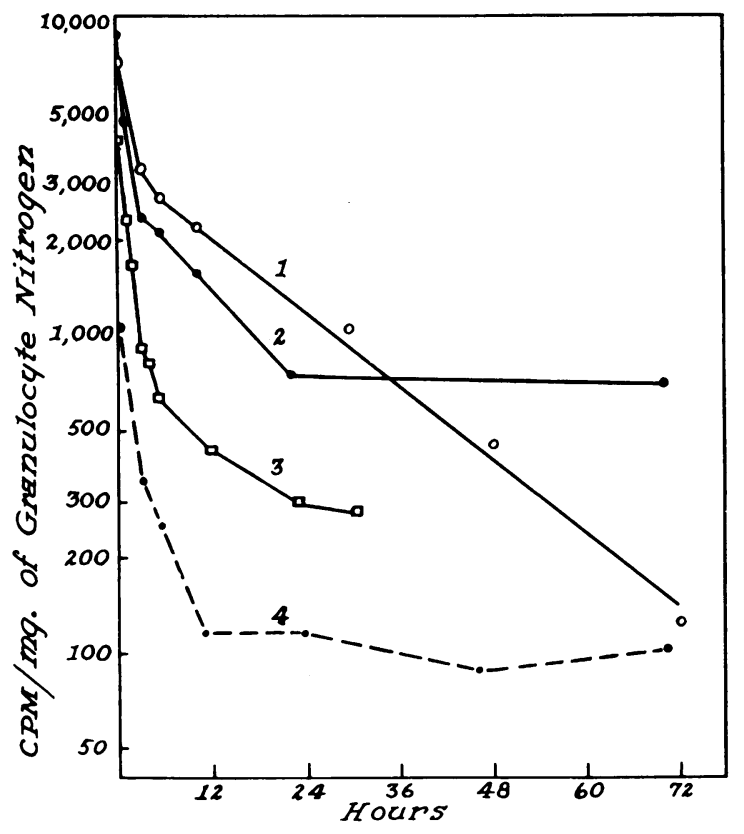

Fig. 5. Curves for bloOd granulocyte SPECIfic aCTIVITY OBSERVED WHEN ISOLOGOUS BLOOD FROM PATIENTS WITH CHRONIC MYELOCYTIC LEUKEMIA WAS TRANSFUSED INTO HEMATOLOGICALLY NORMAL HUMAN SUBJECTS (curves $1,2,3$ ). Curve 4 was obtained after the infusion of autologous normal bone marrow.

lapse. These data together with the three comparable studies reported by Mauer and Jarrold (7) comprise the only quantitative information on the size of the blood granulocyte pool (TBGP) in this disease. We observed higher TBGP values than did Mauer and Jarrold. This is probably due to the fact that a few patients with much higher blood granulocyte counts were studied by us than by these authors. They raised some question as to the validity of pool size estimations in CML. However, several findings in the present study lead us to believe that the size of the TBGP can be measured as accurately in this disease as in normal subjects. Thus, in the epinephrine studies (Table V) no change in differential cell counts or BGSA accompanied the mobilization of large numbers of granulocytes from the MGP. This indicates that cells in the CGP and MGP are in equilibrium, as is the case in normal subjects (2), and that there is no selective sequestration of immature cell forms. In addition, good correlation was found between granulocyte count and TBGP size when single exponential BGSA curves were obtained (Figure 1). It is true that TBGP values calculated from extrapolated zero time $\left(t_{0}\right)$ values were unusually high in subjects with type $B$ curves (Figure 3). However, TBGP calculated from the determined $t_{0}$ values (the mean of triplicate samples was used) almost invariably gave values consistent with those expected from the granulocyte count (Figure 1). It therefore seems that the TBGP calculated from the determined $t_{0}$ value gives a good approximation of TBGP size in most instances regardless of the shape of the subsequent BGSA curve.

The distribution of cells in the CGP and MGP of patients in relapse was similar to that in normal subjects (Figure 2). This is in contrast to the findings in patients with polycythemia vera and myelofibrosis in whom, as the TBGP increased in size, an increasing proportion of granulocytes accumulated in the MGP (10).

In all patients with CML in relapse the disappearance of labeled cells from the blood was much slower than in normal subjects or in patients with most other types of neutrophilia (10). This was true in patients with complex BGSA curves (types $B$ and $C$ ) as well as in patients with single exponential BGSA curves (type A). This finding, coupled with the demonstration that as patients were brought into remission the BGSA curve returned toward and finally reached normal ( Tables II and III and Figure 6), is most provocative. Several possible explanations for this have been considered, but no single one seems entirely adequate.

One possible explanation for the slow decrease in BGSA might be the presence of increased numbers of labeled myelocytes and metamyelocytes in the blood of patients with CML in relapse as compared with the blood of normal persons. [Myeloblasts and promyelocytes do not accept the label (11)]. It is of interest that $t_{1}$ values similar to those found in CML have been encountered in only several other studies, all in patients thought to have myelofibrosis but with differential leukocyte counts similar to that seen in CML (10).

Craddock postulated that immature cells may circulate longer than mature forms (12). Jaffé (13) demonstrated that young cell forms do not enter the exudates associated with fatal infections 


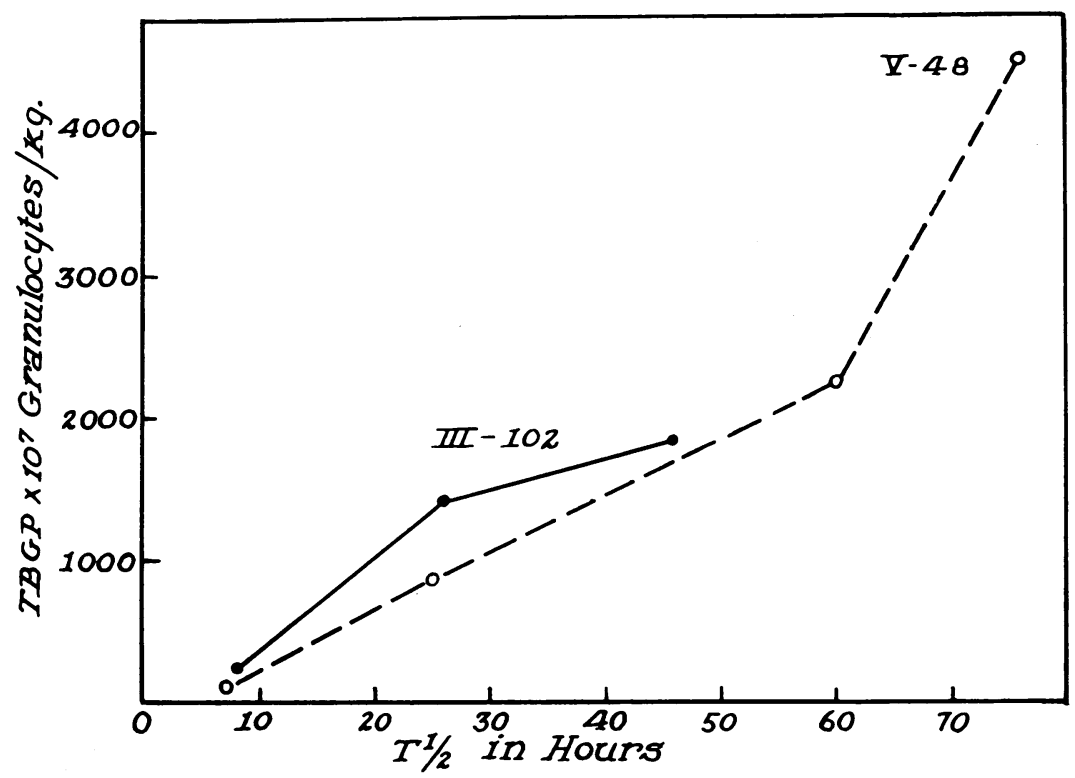

Fig. 6. Relationship between total blood granulocyte pool (TBGP) Size AND T $\frac{1}{2}$ IN TWO PATIENTS STUDIED AT SEVERAL PERIODS DURING THE COURSE OF THEIR DISEASE. The measurements made at different times are joined by a continuous and an interrupted line in these patients.

in patients with leukemia. Boggs (14) and $\mathrm{Pe}-$ rillie and Finch (15) confirmed these findings by producing experimental inflammations. They demonstrated that myelocytes do not leave the blood to enter sites of inflammation and metamyelocytes do so only in small numbers. If, as such studies suggest, the rate of efflux of granulocytes from the blood is related to their stage of maturity, the slow decline of blood granulocyte radioactivity in CML is understandable. The correlation found between the percentage of immature cells and the $t_{z}(r=+0.58$ to +0.61$)$, the slow decrease in blood granulocyte radioactivity seen in the hematologically normal subjects given labeled CML blood and in the subject given labeled bone marrow (Figure 5), and the normal $t_{1}$ encountered when patients with CML were transfused with isologous normal blood (Table V) are compatible with this hypothesis. The last mentioned observations, however, must be interpreted with caution since it appears from preliminary studies that infused isologous granulocytes are different kinetically from autologous granulocytes (16).

It is necessary to consider whether the slow decrease in BGSA can be attributed to other causes than the prolonged circulation of immature forms of granulocytes. Since a single exponential BGSA curve was encountered in 12 of 23 studies on patients in relapse it would appear that mature and immature cells left the blood at the same rate in these subjects. Furthermore, in some patients in remission but with considerable numbers of immature cells present in their blood, a normal rate of decrease in BGSA was observed (Table III). Neither of these observations is compatible with the hypothesis that a slow decrease in BGSA in patients with CML in relapse is due solely to the continued circulation of labeled myelocytes and metamyelocytes.

A slow decrease in BGSA could also be explained on the basis of a large pool (TBGP) with a smaller than normal fractional turnover rate. The correlation between TBGP size and the $t_{3}$ $(r=+0.67, p=<0.001)$ is compatible with this thesis. This hypothesis seems especially attractive since, as the disease is brought under control, the TBGP and $t_{1}$ return to normal values even in patients who exhibit no appreciable change in differential cell count (Patient V-48 in Figure 6). However, that TBGP size alone does not determine the $t_{1}$ is indicated by the findings in 


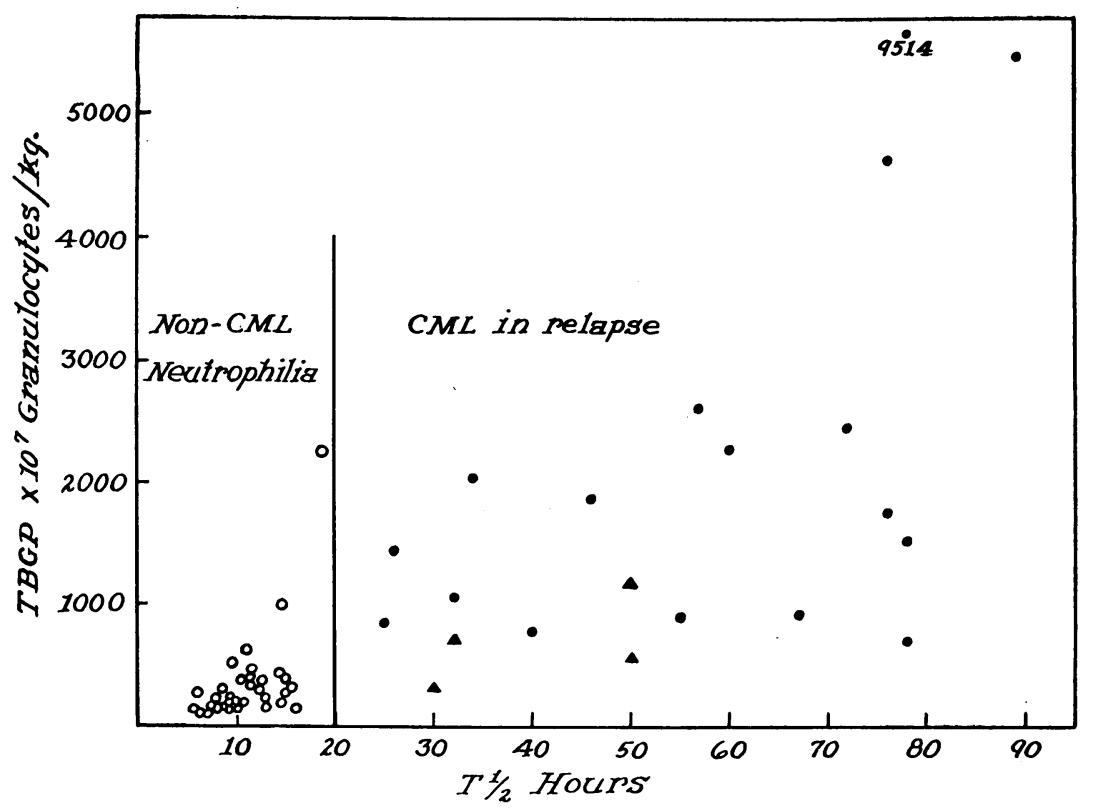

Fig. 7. Relationship of total blood granulocyte pool (TBGP) to ti in PATIENTS WITH CHRONIC MYELOCYTIC LEUKEMIA (CML) IN RELAPSE AS COMPARED WITH PATIENTS WITH NEUTROPHILIA OF OTHER TYPES (POLYCYTHEMIA VERA, SUBACUTE AND CHRONiC infection, AND miscellaneous disorders). Solid circles (O) refer to patients with $\mathrm{CML}$ in relapse. Hollow circles (O) represent nonCML neutrophilias. The triangles $(\boldsymbol{\Delta})$ depict studies in patients with myelofibrosis but with myelocytes and metamyelocytes in the blood in about the same numbers as in patients with CML in relapse.

Patients IV-76 and III-38 (Table III), in whom the TBGP size was normal but the $t_{\frac{1}{2}}$ was markedly prolonged, and from the TBGP size and $t_{\frac{1}{2}}$ values encountered in patients with CML as compared with those in patients with other diseases (Figure 7) (10). At comparable TBGP sizes, patients with CML have considerably longer $t_{\frac{1}{2}}$ values than do patients with other forms of neutrophilia not characterized by the presence of immature granulocytes in the blood. In addition, if a long $t_{1}$ occurred only as a result of large TBGP size, normal compatible cells given to patients with CML would be expected to have a long $t_{1}$. This was not the case (Table V).

The fact that myelocytes bind more $\mathrm{DFP}^{32}$ per cell than more mature forms exposed to the same concentrations of label (11) and the demonstration by Monti, Maloney, Weber, and Patt (17) that at least some of the immature cell forms in the blood of patients with CML divide and mature into segmented neutrophils add to the difficulty of interpreting the decline in the BGSA curve and permit one to postulate still other explanations for the long $t_{\frac{1}{2}}$ in these patients. These are being explored.

The inability of immature cell forms to enter inflammatory exudates $(14,15)$ suggests that the rate of egress of granulocytes from the blood may vary with their stage of maturity. However, it may be argued that such variability in cell disappearance rates should result in a biphasic or more complex curve, not in a single exponential BGSA curve. In this respect, it is noteworthy that it has not yet been demonstrated that blood granulocytes disappear from the blood only to enter sites of tissue injury and inflammation or that such egress determines the blood granulocyte turnover rate. Not only is there evidence that granulocytes are normally lost via such sites as the lungs (18), oral cavity $(18,19)$, and urinary tract $(20)$, in the absence of any evidence of infection, but, in addition, it is recognized that immature as well as mature granulocytes are found in many tissues in patients with CML and perhaps reached such sites via the 
blood. Although the validity of the calculation of GTR in CML cannot be accepted without reservation as pointed out previously ( 7$)$, since in 12 of the 23 studies on patients in relapse a single exponential BGSA curve was obtained, and since the sum of a spectrum of first order granulocyte disappearance rates could not give a single exponential curve (21), the calculation of GTR in these subjects perhaps is valid. If we assume this to be the case, GTR values in CML range from normal to 12 times the normal mean value ( Table I).

Unfortunately, our own GTR values and those of Mauer and Jarrold cannot be compared with similar values obtained by other methods since none are available at present. Nevertheless, if urinary uric acid excretion values have any significance as an indication of cellular turnover, they support the hypothesis that there is a moderate increase in cell turnover in CML (22-24).

There is good evidence for differences in cell enzyme concentration (25) and chromosome make-up (26) in CML leukocytes as compared to normal granulocytes. However, several patients thought to have myelofibrosis and with immature granulocytes in their blood showed a kinetic pattern similar to that seen in CML (10). Detailed leukocyte enzyme analyses and chromosome studies are not available for these patients. However, the leukocyte alkaline phosphatase values in several of them were in the normal range (10). This fact and the prolonged elevation of BGSA after the infusion of normal bone marrow granulocytes (Figure 5) make us reluctant at this time to accept the hypothesis that CML granulocytes are kinetically different from normal cells of the same morphologic type.

The several different types of curves (Figure 1 , panels 2 and 4) encountered in these studies deserve further comment. The first order or random disappearance of granulocytes from the blood in over one-half of these studies is the same as was encountered in 56 of 59 normal subjects and denotes a single granulocyte disappearance rate. The seven studies in which a rapid decrease in BGSA occurred during the first several hours after transfusion and was followed by a single exponential curve (Figure 1, curve B) can be explained in several ways. Two populations of cells, one with a rapid $t_{\frac{1}{2}}$ and the other with a slow $t_{\frac{1}{2}}$ could give such a curve. A more likely explanation is that in some studies a portion of the labeled cells was damaged while the remainder was not, and after infusion the damaged cells were removed from the blood while the undamaged cells remained. The finding that in subjects with type $B$ curves the TBGP calculated from the determined $t_{0}$ value was consistent with the granulocyte count (Figure 2) whereas the extrapolated $t_{0}$ value resulted in unusually high TBGP values, suggests this possibility.

A pertinent question remains, however. Why are several hours required for the removal of the damaged cells? The only answer we can give is to cite our experience with the removal of purposely damaged, $\mathrm{DFP}^{32}$-labeled granulocytes (Table IV). In eight of ten studies in which granulocytes were damaged by incubation for 8 or 16 hours outside the body, and were then labeled with $\mathrm{DFP}^{32}$ and infused, the BGSA curve was of the type $\mathrm{B}$ configuration. The mean TBGP calculated from the determined $t_{0}$ radioactivity values was twice normal in the 8-hour group and six times normal in the 16-hour group, and the extrapolated TBGP values were extremely large. In eight studies in which the cells were incubated for 24 hours, labeled, and infused, two curves were of the $B$ configuration, whereas in the remaining six the radioactivity values were too low to obtain a curve. The mean determined TBGP in the group was ten times normal. From these results it seems that granulocytes damaged during incubation are removed from the blood and that the rate of removal may be related to the degree of damage, less severely damaged cells remaining in the circulation for up to several hours.

It is possible that type $\mathrm{C}$ curves may also reflect cell damage in some way. However, no such curves were encountered in the studies just cited in which cells were intentionally damaged. Other explanations such as an equilibration of blood granulocytes with a large mass of cells in extravascular sites could explain type $C$ curves. However, since type $\mathrm{C}$ curves were seen in patients with CML in remission as well as in relapse, in patients with other diseases (10), and in occasional normal subjects, it seems more likely that these curves reflect a nonsteady state that is not 
evident in the blood granulocyte concentration. One finding in favor of this suggestion is that in patients in whom skin inflammations were produced, type $\mathrm{C}$ curves were common. In these patients there was an increased inflow of cells into the blood from the bone marrow, but no changes in granulocyte concentration were observed. The TBGP enlarged but the enlargement was in the MGP not the CGP (27). It is also possible that type $\mathrm{C}$ curves reflect the presence of several cell populations in the blood, each with a different disappearance rate. This possibility has been discussed already.

\section{Summary}

Blood granulocyte kinetics in chronic myelocytic leukemia has been evaluated by means of the diisopropyl fluorophosphate $\left(\mathrm{DFP}^{32}\right)$ in vitro technic. Forty-three studies were carried out in 29 patients in all phases of their disease. Chronic myelocytic leukemia in relapse was characterized by marked enlargement of the total blood granulocyte pool (10 to 150 times normal) and a prolonged blood granulocyte disappearance time (4 to 12 times normal). With appropriate therapy these kinetic parameters returned to normal. The blood granulocyte count was a good index of the degree of blood granulocyte pool enlargement since both the circulating and marginal granulocyte pools were enlarged and there was no selective sequestration of immature granulocytes in marginal sites. The prolonged blood granulocyte disappearance time appeared to be related to the presence of immature granulocytes in the blood and the size of the blood granulocyte pool and may have been influenced by other unknown factors as well. No support was found for the hypothesis that the granulocytes of chronic myelocytic leukemia are different kinetically from normal granulocytes of the same morphologic type.

\section{Acknowledgments}

We gratefully acknowledge the capable technical assistance of Doris Kurth, Joyce Rose, June Hudson, Vreni Oberholzer, and Anne B. Stryjewski.

\section{References}

1. Mauer, A. M., J. W. Athens, H. Ashenbrucker, G. E. Cartwright, and M. M. Wintrobe. Leukokinetic studies. II. A method for labeling granulocytes in vitro with radioactive diisopropylfluorophosphate $\left(\mathrm{DFP}^{32}\right)$. J. clin. Invest. 1960, 39, 1481.

2. Athens, J. W., S. O. Raab, O. P. Haab, A. M. Mauer, H. Ashenbrucker, G. E. Cartwright, and M. M. Wintrobe. Leukokinetic studies. III. The distribution of granulocytes in the blood of normal subjects. J. clin. Invest. 1961, 40, 159.

3. Athens, J. W., O. P. Haab, S. O. Raab, A. M. Mauer, H. Ashenbrucker, G. E. Cartwright, and M. M. Wintrobe. Leukokinetic studies. IV. The total blood, circulating and marginal granulocyte pools and the granulocyte turnover rate in normal subjects. J. clin. Invest. 1961, 40, 989.

4. Athens, J. W., A. M. Mauer, S. O. Raab, O. P. Haab, and G. E. Cartwright. Studies of granulocyte kinetics (abstract). J. clin. Invest. 1960, 39, 969.

5. Raab, S. O., J. W. Athens, O. P. Haab, D. R. Boggs, G. E. Cartwright, and M. M. Wintrobe. Leukokinetic studies in chronic myelocytic leukemia (CML) using radioactive diisopropylfluorophosphate $\left(\mathrm{DFP}^{32}\right)$. Blood 1962, 20, 803.

6. Cartwright, G. E., J. W. Athens, O. P. Haab, S. O. Raab, D. R. Boggs, and M. M. Wintrobe. Blood granulocyte kinetics in conditions associated with granulocytosis. Ann. N. Y. Acad. Sci. 1964, 113, 963.

7. Mauer, A. M., and T. Jarrold. Granulocyte kinetic studies in patients with proliferative disorders of the bone marrow. Blood 1963, 22, 125.

8. Sacchetti, C. La Granulocitopoiesi Fisiopatologia E. Clinica. Milan, Fondazione Ganassini, 1963.

9. Osgood, E. E., I. E. Brownlee, M. W. Osgood, D. M. Ellis, and W. Cohen. Total differential and absolute leukocyte counts and sedimentation rates for healthy persons 19 years of age and over. Arch. intern. Med. 1939, 64, 105.

10. Athens, J. W., O. P. Haab, S. O. Raab, D. R. Boggs, H. Ashenbrucker, G. E. Cartwright, and M. M. Wintrobe. Leukokinetic studies. XI. Blood granulocyte kinetics in polycythemia vera, infection, and myelofibrosis. J. clin. Invest. 1965, 44, 000.

11. Kurth, D., J. W. Athens, E. P. Cronkite, G. E. Cartwright, and M. M. Wintrobe. Leukokinetic studies. V. Uptake of tritiated diisopropylfluorophosphate by leukocytes. Proc. Soc. exp. Biol. (N. Y.) 1961, 107, 422.

12. Craddock, C. G., Jr. The physiology of granulocytic cells in normal and leukemic states. Amer. J. Med. 1960, 28, 711.

13. Jaffé, R. H. Morphology of the inflammatory defense reactions in leukemia. Arch. Path. 1932, 14, 177.

14. Boggs, D. R. The cellular composition of inflammatory exudates in human leukemias. Blood 1960, 15, 466. 
15. Perillie, P. E., and S. C. Finch. The local exudative cellular response in leukemia. J. clin. Invest. 1960, 39, 1353.

16. Athens, J. W. Unpublished observations.

17. Monti, A., M. A. Maloney, C. L. Weber, and H. H. Patt. Comparison of cell renewal in normal and leukemic states (abstract). Blood 1961, 18, 793.

18. Ambrus, C. M., and J. L. Ambrus. Regulation of the leukocyte level. Ann. N. Y. Acad. Sci. 1959, 77, 445 .

19. Fliedner, T. M., E. P. Cronkite, and J. S. Robertson. Granulocytopoiesis I. Senescence and random loss of neutrophilic granulocytes in human beings. Blood 1964, 24, 402.

20. Addis, T. Glomerular Nephritis: Diagnosis and Treatment. New York, Macmillan, 1952.

21. Van Liew, H. D. Semilogarithmic plots of data which reflect a continuum of exponential processes. Science 1962, 138, 682.
22. Sandberg, A. A., G. E. Cartwright, and M. M. Wintrobe. Studies on leukemia. I. Uric acid excretion. Blood 1956, 11, 154.

23. Nugent, C. A., W. D. MacDiarmid, and F. H. Tyler. Renal excretion of uric acid in leukemia and gout. Arch. intern. Med. 1962, 109, 540.

24. Weissman, S. M., M. Lewis, and M. Karon. Pseudouridine metabolism. IV. Excretion of pseudouridine and other nitrogenous metabolites in chronic leukemia. Blood 1963, 22, 657.

25. Valentine, W. N. The metabolism of the leukemic leukocyte. Amer. J. Med. 1960, 28, 699.

26. Nowell, P. C., and D. A. Hungerford. Chromosome changes in human leukemia and a tentative assessment of their significance. Ann. N. Y. Acad. Sci. 1964, 113, 654.

27. Boggs, D. R., J. W. Athens, G. E. Cartwright, and M. M. Wintrobe. Masked granulocytosis. Proc. Soc. exp. Biol. (N. Y.), in press. 